\title{
Hubungan antara Status Gizi dengan Prestasi Belajar Siswa SDN 03 Pondok Cina Depok Tahun 2015
}

\author{
Tazkya Amany, Rini Sekartini \\ Departemen Ilmu Kesehatan Anak Fakultas Kedokteran Universitas Indonesia/RS Dr. Cipto Mangunkusumo, Jakarta
}

\begin{abstract}
Latar belakang. Di Indonesia, kondisi status gizi anak usia sekolah tergolong buruk sehingga menempatkan Indonesia sebagai negara dengan peringkat indeks pembangunan manusia yang rendah. Status gizi merupakan salah satu faktor yang dapat berpengaruh terhadap prestasi belajar.

Tujuan. Mengetahui hubungan antara status gizi dengan prestasi belajar siswa SDN 03 Pondok Cina.

Metode. Penelitian dilaksanakan bulan Oktober 2015 sampai dengan September 2016 dengan desain potong lintang analitik. Jumlah subjek penelitian 179 siswa. Pengambilan data dilakukan dengan pengukuran BB dan TB, pengisian kuesioner faktor sosiodemografi, dan pendataan nilai rapor. Data dianalisis dengan menggunakan uji chi square.

Hasil. Berdasarkan indeks BB/TB, sebagian besar siswa memiliki status gizi normal (46,40\%), obesitas (21,20\%), gizi kurang (20,10\%), dan gizi lebih (12,30\%). Terdapat lebih banyak siswa dengan prestasi belajar yang rendah pada mata pelajaran Bahasa Indonesia $(50,80 \%)$, matematika $(53,60 \%)$, dan IPA $(50,30 \%)$. status gizi (dibagi menjadi normal dan tidak normal). Terdapat hubungan status gizi yang bermakna secara statistik dengan prestasi belajar Bahasa Indonesia ( $p=0,019)$ dan IPA ( $p=0,029)$.

Kesimpulan. Terdapat hubungan antara status gizi dengan prestasi belajar Bahasa Indonesia dan IPA pada siswa SDN 03 Pondok Cina. Sari Pediatri 2017;18(6):487-91
\end{abstract}

Kata kunci: status gizi, prestasi belajar, siswa

\section{Association between Nutritional Status and Academic Performance among Students at SDN 03 Pondok Cina Depok 2015}

Tazkya Amany, Rini Sekartini

Background. In Indonesia, nutritional status condition shown by school-aged children is poor so that Indonesia has been ranked as a country with low Human Development Index. Nutritional status is one of many factors that may influence academic performance. Objective. To find the relationship between nutritional status and academic performance among students at SDN 03 Pondok Cina. Method. This study was held in October 2015 until September 2016 with analytical cross sectional design and 179 subjects were involved. The data were collected through body weight and height measurement, along with sociodemographic factor questionnaire and grades fulfillment. The data were analyzed by using Chi-Square test.

Result. According to BW/BH index, the majority of students had normal nutritional status (46.40\%), followed by obesity (21.20\%), moderate underweight $(20.10 \%)$, and overweight $(12.30 \%)$. There were also more students who had low academic performance in Indonesian Languange (50.80\%), Mathematics (53.60\%), and Science (50.30\%) subject. The result showed that nutritional status (categorized into normal and abnormal) had significant association with academic performance in Indonesian Languange ( $\mathrm{p}=0.019$ ) and Science $(\mathrm{p}=0.029)$ subject.

Conclusion. Nutritional status had significant association with academic performance in Indonesian Languange and Science subject among students at SDN 03 Pondok Cina. Sari Pediatri 2017;18(6):487-91

Keywords: nutritional status, academic performance, students

Alamat korespondensi: Tazkya Amany. DR. Dr. Rini Sekartini, SpA(K). Departemen Ilmu Kesehatan Anak Fakultas Kedokteran Universitas Indonesia/RS Dr. Cipto Mangunkusumo, Jakarta. E-mail: tazkya95@gmail.com 
S tatus gizi merupakan salah satu faktor yang dapat berpengaruh terhadap prestasi belajar di samping faktor lain, seperti faktor keluarga, lingkungan, motivasi, serta sarana, dan prasarana yang didapatkan di sekolah. ${ }^{1}$ Anak usia sekolah tidak termasuk ke dalam kelompok yang memiliki risiko kematian tinggi. Meskipun demikian, masalah gizi berupa gizi kurang dan gizi lebih perlu mendapat perhatian demi tercapainya 'tujuan pembangunan millenium development goals (MDGs), yaitu pada masalah penanggulangan kemiskinan dan kelaparan, serta pendidikan dasar untuk semua., ${ }^{2,3}$

Sampai saat ini, Indonesia merupakan negara yang menempati peringkat indeks pembangunan manusia (IPM) yang rendah, antara lain, dipengaruhi kondisi status gizi dan kesehatan penduduk yang buruk. ${ }^{4}$ Gambaran status gizi anak usia sekolah (5-12 tahun) di Indonesia (Riskesdas 2013) memperlihatkan prevalensi skala nasional status gizi sangat kurus $4,4 \%$ (laki-laki) dan 3,5\% (perempuan), status gizi kurus 7,7\% (lakilaki) dan $6,7 \%$ (perempuan), status gizi gemuk 10,8\% (laki-laki) dan 10,7\% (perempuan), serta status gizi obesitas 9,7\% (laki-laki) dan 6,6\% (perempuan). ${ }^{5}$ Faktor utama yang berperan pada gizi kurang adalah kondisi sosioekonomi dan tingkat penyakit infeksi dan menular yang tinggi. ${ }^{2}$ Pada sisi lain, prevalensi obesitas pada anak usia sekolah diperkirakan akan terus meningkat. ${ }^{6}$ Berdasarkan data penelitian prevalensi gizi lebih atau obesitas anak usia sekolah dasar yang dilakukan di sepuluh kota besar di Indonesia pada tahun 2004, didapatkan berkisar pada angka $12 \%{ }^{6}$

Terdapat beberapa penelitian yang sudah dilakukan dengan hasil yang berbeda untuk mengetahui hubungan antara status gizi dan prestasi belajar pada anak usia sekolah. Perbedaan hasil penelitian tersebut dapat dipengaruhi oleh peran faktor lebih dominan dari selain status gizi ataupun cara pengambilan serta interpretasi data yang berbeda antar peneliti. Masalah gizi anak usia sekolah di Kota Depok belum dapat ditetapkan dengan pasti karena program perbaikan gizi lebih difokuskan pada anak berusia di bawah lima tahun (balita). ${ }^{7}$ Berdasarkan latar belakang tersebut, perlu dilakukan penelitian mengenai status gizi dan hubungannya dengan prestasi belajar siswa SDN 03 Pondok Cina, Depok.

\section{Metode}

Penelitian desain cross sectional (potong lintang) dan dilakukan di SDN 03 Pondok Cina pada Januari 2016. Sampel ditetapkan dari SDN 03 Pondok Cina dengan metode pengambilan data menggunakan kuesioner sosiodemografi dan pengukuran berat badan serta tinggi badan untuk menilai status gizi serta pendataan nilai rapor terakhir siswa untuk menilai prestasi belajar. Kriteria inklusi merupakan siswa kelas 2, 3, 4 atau 5 SDN 03 Pondok Cina tahun ajaran 2015/2016, datang pada saat pengukuran berat badan dan tinggi badan, mengisi data pada kuesioner, dan memiliki data nilai rapor semester ganjil tahun ajaran 2015/2016 di SDN 03 Pondok Cina, Depok. Kriteria eksklusi adalah tidak mengisi lembar informed consent dan data pada kuesioner tidak lengkap.

Dengan rumus sampel tunggal, didapatkan jumlah sampel minimal 96 sampel yang kemudian ditambahkan dengan perkiraan drop out (10\%) sehingga didapatkan besar sampel sebanyak 106 sampel. Pengambilan sampel dilakukan dengan metode total sampling pada tiap tingkatan kelas. Data yang digunakan merupakan data primer yang diperoleh melalui pengukuran berat badan dan tinggi badan untuk menilai status gizi, pengisian kuesioner untuk menilai faktor sosiodemografi, dan pendataan nilai rapor semester ganjil tahun ajaran 2015/2016 untuk menilai prestasi belajar siswa. Setelah mendapatkan data dengan jumlah yang sesuai, data akan diolah terlebih dahulu. Data yang diolah adalah data untuk penentuan indeks $\mathrm{BB} / \mathrm{TB}$ dan rata-rata nilai rapor tiap kelas pada mata pelajaran yang telah ditentukan. Pada analisis bivariat, uji statistik chi-square dilakukan dengan perangkat lunak SPSS versi 20 untuk menentukan kemaknaan hubungan antara variabel kategorik bila memenuhi syarat. Nilai $\alpha$ ditetapkan 0,05 dengan interval kepercayaan 95\%.

Penelitian ini telah mendapatkan persetujuan etik dari Pengelola Modul Riset Fakultas Kedokteran Universitas Indonesia.

\section{Hasil}

Di antara 219 siswa kelas 2, 3, 4, dan 5 SDN 03 Pondok Cina, 179 siswa mengisi kuesioner faktor sosiodemografi dengan lengkap serta mengikuti pengukuran berat badan dan tinggi badan. Berdasarkan variabel status gizi, tidak terdapat subjek yang memiliki status gizi berupa gizi buruk, sebagian besar subjek memiliki status gizi normal $(46,40 \%)$. Sebaran 
karakteristik subjek berdasarkan status gizi dan prestasi belajar tertera pada Tabel 1. Sebaran karakteristik subjek berdasarkan faktor sosiodemografi tidak tertera dalam tabel tersebut.

Setelah dilakukan uji statistik chi-square, prestasi belajar Bahasa Indonesia dan IPA memiliki hubungan bermakna secara statistik dengan status gizi $(\mathrm{p}<0,05)$. Hubungan antara status gizi dengan prestasi belajar tertera pada Tabel 2. Hasil analisis hubungan antara faktor sosiodemografi (meliputi usia, jenis kelamin, usia ayah, usia ibu, jumlah saudara kandung, urutan kelahiran, pendidikan ayah, pendidikan ibu, pekerjaan ayah, pekerjaan ibu, pendapatan ayah, pendapatan ibu,

Tabel 1. Karakteristik subjek berdasarkan status gizi dan prestasi belajar

\begin{tabular}{lcc}
\hline Variabel & Jumlah (n) & Persentase (\%) \\
\hline Status gizi & & \\
Buruk & 0 & 0,00 \\
Kurang & 36 & 20,10 \\
Normal & 83 & 46,40 \\
Lebih/overweight & 22 & 12,30 \\
Obesitas & 38 & 21,20 \\
Prestasi belajar & & \\
Bahasa Indonesia & & \\
Tinggi & 88 & 49,20 \\
Rendah & 91 & 50,80 \\
Matematika & & \\
Tinggi & 83 & 46,40 \\
Rendah & 96 & 53,60 \\
IPA & & \\
Tinggi & 89 & 49,70 \\
Rendah & 90 & 50,30 \\
\hline
\end{tabular}

Tabel 2. Hubungan antara status gizi dengan prestasi belajar

\begin{tabular}{llll}
\hline Prestasi belajar & \multicolumn{2}{c}{ Status gizi } & $\mathrm{p}$ \\
\cline { 2 - 3 } & Normal (\%) & $\begin{array}{c}\text { Tidak } \\
\text { normal (\%) }\end{array}$ & \\
\hline $\begin{array}{l}\text { Bahasa Indonesia } \\
\quad \text { Tinggi }\end{array}$ & $33(39,8)$ & $55(57,3)$ & 0,019 \\
$\quad$ Rendah & $50(60,2)$ & $41(42,7)$ & \\
Matematika & & & \\
$\quad$ Tinggi & $32(38,6)$ & $51(53,1)$ & 0,051 \\
$\quad$ Rendah & $51(61,4)$ & $41(46,9)$ & \\
IPA & & & \\
$\quad$ Tinggi & $34(41,0)$ & $55(57,3)$ & 0,029 \\
$\quad$ Rendah & $49(59,0)$ & $41(42,7)$ & \\
\hline
\end{tabular}

dan bentuk keluarga) dengan prestasi belajar Bahasa Indonesia, matematika, dan IPA tidak tertera dalam Tabel.

\section{Pembahasan}

Berdasarkan variabel status gizi, diperoleh bahwa sebagian besar subjek memiliki status gizi normal (46,40\%), obesitas $(21,20 \%)$, gizi kurang $(20,10 \%)$, dan gizi lebih (12,30\%). Hal ini sesuai dengan teori yang dikemukakan oleh Notoadmodjo ${ }^{8}$ bahwa kelompok anak usia 6-12 tahun merupakan kelompok usia yang rentan terhadap masalah terkait dengan kekurangan gizi yang dicirikan oleh berat badan rendah dan defisiensi zat besi. Penelitian ini juga sesuai dengan penelitian yang dilakukan oleh Hidayati ${ }^{7}$ yang melaporkan bahwa terdapat beberapa faktor yang sangat berperan dalam kondisi status gizi anak usia sekolah, di antaranya yaitu asupan makanan, aktivitas fisik, dan kondisi sosioekonomi.'

Terdapat hubungan yang bermakna antara status gizi dengan prestasi belajar bahasa Indonesia dan IPA. Umami juga ${ }^{10}$ melaporkan hasil penelitian hubungan antara status gizi dan prestasi belajar. Pada penelitian tersebut, sampel merupakan siswa kelas 5 dan 6 di MI (madrasah ibtidaiyah) yang setara dengan jenjang sekolah dasar dan prestasi belajar yang dinilai berdasarkan rerata nilai rapor mata pelajaran Bahasa Indonesia, matematika, IPA, dan IPS (ilmu pengetahuan sosial). Penelitian Hartini $\mathrm{dkk}^{6}$ mengenai hubungan antara derajat obesitas dengan prestasi belajar anak usia sekolah menunjukkan bahwa terdapat hubungan antara derajat obesitas dengan prestasi belajar pada mata pelajaran matematika dan Bahasa Indonesia siswa sekolah dasar. Semakin tinggi derajat obesitas, semakin besar risiko seseorang mengalami komplikasi penyakit kronis. Selain itu, pada anak usia sekolah, obesitas memberikan dampak tidak langsung terhadap penurunan fungsi kognitif. Diduga, dampak tidak langsung sebagai akibat penyakit yang diderita oleh anak dengan obesitas (diabetes, gangguan tidur berupa obstructive sleep apnea (OSAS), dan masalah respirasi), masalah psikososial, dan kematangan sosial.

Di sisi lain, tidak terdapat hubungan antara status gizi dengan prestasi belajar matematika. Sejalan dengan penelitian yang dilakukan oleh Puspitasary $\mathrm{dkk}^{11}$ yang melaporkan bahwa tidak terdapat hubungan antara status gizi dengan prestasi belajar matematika pada siswa kelas 4 dan 5 sekolah dasar. Satya ${ }^{12}$ melaporkan 
bahwa status gizi tidak selalu memengaruhi prestasi belajar. Hal tersebut disebabkan oleh beberapa faktor, salah satunya keluarga yang menjadi pusat pendidikan utama dan pertama, seperti dalam hal mendidik anak, hubungan orang tua dengan anak, bimbingan orang tua, pendidikan orang tua, suasana rumah, dan keadaan ekonomi keluarga.

Kami mendapatkan bahwa sebagian besar siswa memiliki status gizi tidak normal, tetapi memperlihatkan prestasi belajar yang tinggi pada mata pelajaran bahasa Indonesia, matematika, dan IPA. Hal tersebut terjadi karena terdapat faktor internal dan eksternal yang lebih berperan dalam menentukan prestasi belajar subjek. Faktor internal yang berpengaruh besar adalah minat dan motivasi. Sementara faktor lain, terutama di lingkungan sekolah, adalah sarana dan prasarana pembelajaran yang tersedia, termasuk metode pengajaran yang diterapkan oleh para guru di sekolah. Hal tersebut dapat dijelaskan dengan teori taksonomi yang dijelaskan oleh Bloom ${ }^{13}$ bahwa terdapat dua faktor utama yang berperan dominan terhadap hasil belajar, yaitu karakteristik siswa yang meliputi kemampuan, minat, hasil belajar sebelumnya, dan motivasi, serta karakter pengajaran yang meliputi guru dan fasilitas belajar.

Prestasi belajar subjek pada ketiga mata pelajaran memiliki hubungan dengan tingkat pendapatan ayah. Sebagian besar subjek memiliki ayah dengan tingkat pendapatan tinggi. Sebagian besar siswa berstatus gizi tidak normal, tetapi memperlihatkan prestasi belajar yang tinggi pada ketiga mata pelajaran. Hal tersebut kemungkinan juga disebabkan oleh karakteristik siswa yang umumnya berasal dari keluarga dengan tingkat ekonomi tinggi (di atas garis kemiskinan). Orang tua, terutama ayah dengan tingkat ekonomi tinggi, umumnya dapat memenuhi kebutuhan anak dengan baik dalam hal sarana dan prasarana pendidikan yang dibutuhkan dalam keberlangsungan proses belajarmengajar. Selain itu, hal ini juga dapat terjadi karena tingkat kecerdasan intelektual (IQ/intelligence quotient) siswa juga dapat berpengaruh terhadap prestasi

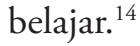

Kami mendapatkan bahwa pendapatan ayah merupakan satu-satunya faktor sosiodemografi yang memiliki hubungan dengan ketiga mata pelajaran. Sementara itu, pendapatan ibu hanya menunjukkan hubungan dengan prestasi belajar IPA. Hal tersebut sesuai dengan penelitian Rodiyah ${ }^{15}$ yang melaporkan bahwa terdapat hubungan antara status sosioekonomi orang tua dengan prestasi belajar siswa. Status sosioekonomi dari segi pendapatan sendiri, terutama ditentukan oleh tingkat pendapatan ayah.

Hubungan antara jenis kelamin dengan prestasi belajar bahasa Indonesia dan IPA dijelaskan oleh Sugihartono ${ }^{16}$ yang melaporkan bahwa terdapat perbedaan gender dalam beberapa aspek terkait dengan kemampuan akademik, di antaranya adalah kemampuan verbal atau kebahasaan. Perempuan lebih bagus dalam mengerjakan tugas verbal di tahun-tahun awal dan dapat mempertahankannya, sementara lakilaki menunjukkan masalah bahasa yang lebih banyak dibandingkan dengan perempuan.

Kami mendapatkan bahwa terdapat hubungan pekerjaan ibu dengan prestasi belajar IPA. Sejalan dengan penelitian Holladay ${ }^{17}$ yang melaporkan bahwa ibu yang bekerja paruh waktu (part-time) memiliki anak dengan prestasi belajar yang lebih baik dibandingkan dengan ibu yang bekerja penuh waktu (full-time). Meskipun begitu, Schildberg-Hörisch ${ }^{18}$ melaporkan bahwa prestasi belajar siswa yang baik lebih dipengaruhi oleh kualitas dibandingkan dengan kuantitas dalam hal waktu yang dihabiskan oleh orang tua bersama dengan anak di rumah.

Kami mendapatkan bahwa prestasi belajar siswa yang rendah lebih banyak terdapat pada mata pelajaran matematika. Prestasi belajar siswa pada mata pelajaran matematika menunjukkan hubungan dengan bentuk keluarga. Suleman $\mathrm{dkk}^{19}$ melaporkan bahwa siswa dengan bentuk keluarga inti/nuclear memiliki prestasi belajar yang lebih baik dibandingkan mereka yang tinggal dalam keluarga dengan bentuk extended. Berdasarkan penelitian yang dilakukan oleh Mbugua $\mathrm{dkk},{ }^{20}$ terdapat banyak faktor yang berkontribusi pada prestasi belajar siswa yang buruk pada mata pelajaran matematika, meliputi tingkat pendidikan terakhir orangtua, tingkat pendapatan orang tua, kondisi kultural, minat, motivasi, dan strategi belajar yang berbeda antarsiswa.

\section{Kesimpulan}

Terdapat hubungan antara status gizi dengan prestasi belajar Bahasa Indonesia dan IPA, sedangkan tidak terdapat hubungan antara status gizi dengan prestasi belajar matematika. Pendapatan ayah merupakan faktor sosiodemografi yang memiliki hubungan dengan prestasi belajar Bahasa Indonesia, Matematika, dan IPA. 


\section{Daftar pustaka}

1. Agustini CC, Malonda NSH, Purba RB. Hubungan antara status gizi dengan prestasi belajar anak kelas 4 dan 5 sekolah dasar di Kelurahan Maasing Kecamatan Tuminting Kota Manado 2013. [Diakses pada 2 May 2015]. Didapat dari: http://fkm.unsrat.ac.id/wp-content/uploads/2013/08/creisyecynthia-agustini.pdf

2. Rosso JMD, Arlianti R. Investasi untuk kesehatan dan gizi sekolah di Indonesia. 2009. [Diakses pada 2 May 2015]. Didapat dari: http://datatopics.worldbank.org/hnp/files/edstats/ IDNwp09a.pdf.

3. Sari A. Strategi dan inovasi pencapaian MDGs di Indonesia. 2015 [Diakses pada 2 May 2015]. Didapat dari: http://www. pustaka.ut.ac.id/dev25/pdfprosiding2/fisip201236.pdf.

4. Hadi H. Beban ganda masalah gizi dan implikasinya terhadap kebijakan pembangunan kesehatan nasional. 2005 [Diakses pada 2 May 2015]. Didapat dari: http://gizi.depkes.go.id/wpcontent/uploads/2011/08/Beban-ganda-masalah_gizi.pdf.

5. Departemen Kesehatan Republik Indonesia. Laporan nasional riset kesehatan dasar 2013. 2013 [Diakses pada 9 Agustus 2015]. Didapat dari: http://biofarmaka.ipb.ac.id/ biofarmaka/2014/Riskesdas2013\%20-\%20Diseminasi\%20 -\%20Status\%20Gizi.pdf.

6. Hartini K, Soetjiningsih, Nurani N. Korelasi derajat obesitas dengan prestasi belajar siswa sekolah dasar. Sari Pediatri 2014;16:1-2.

7. Hidayati RN. Hubungan asupan makanan anak dan status ekonomi keluarga dengan status gizi anak usia ekolah di kelurahan tugu kecamatan cimanggis kota depok. Jurnal Penelitian Kesehatan 2012;7:1-7.

8. Notoadmodjo S. Kesehatan masyarakat ilmu dan seni. Jakarta: PT Rineka Cipta; 2011

9. Supariasa IDN. Penilaian status gizi. Jakarta: EGC; 2004.

10. Umami W. Hubungan pola asuh belajar, imt/u, dan karakteritik siswa terhadap prestasi belajar pada siswa kelas $\mathrm{V}$ dan VI Madrasah Ibtidaiyah Negeri 1 Ciputat tahun 2015, skripsi. Jakarta: Universitas Islam Negeri Syarif Hidayatullah,
2015.

11. Puspitasary I, Bolang AS, Malonda NSH. Hubungan antara status gizi dengan prestasi belajar siswa kelas 4 dan 5 Santa Theresia Malalayang [internet]. 2013 [Diakses pada 20 Juni 2016]. Didapat dari: http://fkm.unsrat.ac.id/wp-content/ uploads/2013/08/Jurnal-Ika-Puspitasary-091511185-Gizi.pdf.

12. Ristiyati ID. Hubungan antara status gizi dan prestasi belajar murid SD negeri di Kecamatan Tuntang Kabupaten Semarang, skripsi. Surakarta: Universitas Muhammadiyah Surakarta, 2014.

13. Universitas Pendidikan Indonesia. Tinjauan teoritis prestasi belajar [internet]. 2016 [Diakses pada 20 Jun 2016]. Didapat dari: http://a-research.upi.edu/operator/upload/s_pek_040076_ chapter2(1).pdf.

14. Anees A. A study of academic achievement in relation to intelligence of class VII students. Excellence Int J Edu Res 2013;1:239-48.

15. Rodiyah. Hubungan status sosial ekonomi orang tua dengan hasil belajar kpmpetensi perawatan kulit wajah bermasalah siswa kelas XI SMK Negeri 6 Padang, skripsi. Padang: Universitas Negeri Padang, 2013.

16. Yuniarti RD. Pengaruh sikap dan gender terhadap prestasi belajar bahasa indonesia pada siswa smp negeri kelas VII di Kecamatan Sleman Yogyakarta 2013/2014, skripsi. Yogyakarta: Universitas Negeri Yogyakarta, 2014.

17. Holladay HM. Mothers' work-to-family conflict and children academic achievement: do school involvement and work status matter?, tesis. Provo: Birmingham Young University, 2013.

18. Schildberg-Hörisch H. Parental employment and children's academic achievement. IZA World of Labor. 2016; 231: 1-10.

19. Suleman Q, Hussain I, Akhtar Z, Khan W. Effects of family structure on the academic achievement of students at elementary level in karak districk, Pakistan. J Soc Res 2012;3:244.

20. Mbugua ZK, Kibet K, Muthaa GM, Nkonke GR. Factors contributing to students' poor performance in mathematics at kenya certificate of secondary education in kenya: a case of baringo county, kenya. Am J Contemporary Res 2012;2:87-91. 